\title{
EFFECT OF BIOPESTICIDS IN CONTROLLING LeAF CURL Virus OF CHILLI
}

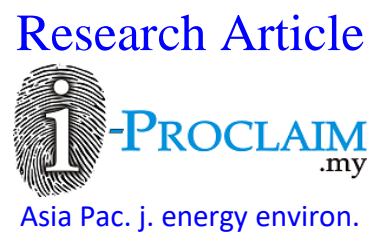

\section{K. M. Khalequzzaman ${ }^{1 *}$, Samima Naznin' ${ }^{2}$, Abul Khair ${ }^{3}$}

${ }^{1}$ Senior Scientific Officer, Spices Research Centre, BARI, Shibganj, Bogra, BANGLADESH
${ }^{2}$ M. Phil. Student, Department of Botany, Jahangirnagar University, Savar, Dhaka, BANGLADESH
${ }^{3}$ Professor, Department of Botany, Jahangirnagar University, Savar, Dhaka, BANGLADESH

*Email for Correspondence: zaman.path@gmail.com

Cell Phone: +8801911762978

Abstract

The experiment was conducted in the field laboratory of Spices Research Center, BARI, Shibganj, Bogra, Bangladesh during Rabi season of 2014-15 to find out the effect of biopesticides in controlling vector as well as leaf curl virus of chilli. The maximum infected plants $(26.85 \%)$ were recorded in untreated control and the minimum infected plants $(14.75 \%)$ were in Malathion $(0.2 \%)$ which was statistically identical to all other biopesticides except cow urine (1:2). The highest disease reduction (45.13\%) over untreated control was obtained from Malathion $(0.2 \%)$ followed by cow urine (1:1) and neem leaf extract (1:2), and the lowest $(26.37 \%)$ was obtained from cow milk (1:2). The highest yield $(18.33 \mathrm{t} / \mathrm{ha})$ was recorded in Malathion $(0.2 \%)$ and the lowest $(11.28 \mathrm{t} / \mathrm{ha})$ was recorded in untreated control. All the biopesticides resulted least disease incidence and more yield compared to control. Among the biopesticides, cow urine (1:1), cow milk (1:1) and neem extract (1:2) showed comparatively better results against control. So, Melathion or biopesticides, cow urine (1:1), cow milk $(1: 1)$ and neem leaf extract (1:2) may be sprayed for controlling vector as well as leaf curl virus and increasing yield of chilli.

Key words

Malathion, cow milk, cow urine, neem leaf extract, leaf curl virus, chilli

\section{INTRODUCTION}

The spice crop chilli (Capsicum annuum L.), known to be originated in tropical Asia, is cultivated in Bangladesh as the most important spice crop both during winter and summer seasons. Chilli is the fruit of the plants from the genus Capsicum belonging to the family Solanaceae. Chilli contains $1.29 \mathrm{mg}$ protein, $11 \mathrm{mg}$ calcium, 870 I.U. vitamin A, 17.5 $\mathrm{mg}$ ascorbic acid, $0.06 \mathrm{mg}$ thiamin, $0.03 \mathrm{mg}$ riboflavin and $0.55 \mathrm{mg}$ niacin per $100 \mathrm{~g}$ edible green fruit (Joshi and Singh, 1975). Capsicum is also known as chilli usually spelt 'chilli' in the United States, paprika, pimiento and sweet, red, cayenne or bird pepper depending upon the type and the way in which it is used. Capsicum in a fresh state is very rich in vitamin C, as cited by Dr. Szent Gyorgyi, the Hungarin scientist, who was awarded the Nobel Prize in 1937 for isolating vitamin C from paprika fruits and showing that they were one of the richest sources available of this vitamin. Capsanthin is the most important pigment of Capsicum. The pungent principle is Capsaicin, which is present in the placenta, and is said to retain its pungency in a dilution of one part in one million.

According to present statistics (Agri Diary, 2012), about 1, 50,000 ha land is under chilli cultivation in Bangladesh during the Rabi season and total production is about 2, 03,000 m. tons per year, approximately and per ha yield is about $1.35 \mathrm{~m}$. tons. During the Kharif season about 35,000 ha of land is brought under chilli cultivation and total production is around $56,000 \mathrm{~m}$. tons per year approximately and per ha yield is $1.59 \mathrm{~m}$. tons. In Bangladesh many factors are responsible for the low yield of the crop. Fungal diseases play a vital role. Chilli is known to suffer from as many as 83 different diseases (Anonymous, 1960 \& 1966; Rangaswami, 1979).

The major disease problem in cultivated Chilli varieties throughout the chilli growing areas in the world is the complex viral infections. Several malformations of the foliage are described as "leaf curl" and these are caused by virus infection transmitted by mites and thrips. In plants with mixed infections of mosaic and leaf curl virus, the leaf curls symptoms are more severe than the mosaic (Sugiura et al., 1975). Leaf curl virus is more prevalent in most chilli growing areas of 
Bangladesh. Chilli leaf curl virus (CLCV) caused vein clearing on young leaves at the early stages of infection, upward or downward curling of young and old leaves and stunting in most cases. Curling of fruits could be seen in mature plants. The virus is transmitted by white fly, Bemisia tabaci (Fernando and Peiris, 1875). The CLCV belongs to the group of circulative viruses such as Euphobia mosaic virus, tobacco leaf curl virus, cucumber vein yellowing virus and others (Suguira et al., 1975). The disease is assumed to cause profuse yield loss. Because of this, the farmers face financial loss every season. So far it is known that the effective control measure of the same is still unknown. The disease may be reduced through vector control. Hence, biopesticides may be used for controlling vector as well as virus of chilli avoiding environmental pollution and health hazards through chemical pesticides. So, the experiment was undertaken to find out the effective of biopesticides, natural products in controlling vector as well as leaf curl virus and increasing yield of chilli.

\section{Materials AND Methods}

The experiment was conducted in the field laboratory of at Spices Research Center, BARI, Shibganj, Bogra, Bangladesh during Rabi season of 2014-15. The experimental plot was prepared with five ploughings and cross ploughings with a power tiller followed by laddering to break the clods as well as level the soil. The weeds and stubbles of previous crops were collected and removed from the soil. Cowdung 5 t/ha, Urea @ 210, TPS @ 300, MOP @ 200 and Gypsum @ 110 $\mathrm{kg} /$ ha were applied (Anonymous, 2011). The entire quantity of cowdung, TSP, half of MOP, Gypsum was applied during final land preparation. Urea and remaining half MOP were applied in three installments as top dress. The experiment was carried out following Randomized Complete Block Design with three replications. Size of the plots was $3.0 \mathrm{~m} \times 2.0 \mathrm{~m}$ and plant spacing was $50 \mathrm{~cm} \times 40 \mathrm{~cm}$. BARI Chilli 1 was used in the experiment. The plants were transplanted on November 16, 2014. Watering was done after planting the seedlings to keep the soil humidity in suitable condition. Gap filling was done when any seedling failed to establish and died in the field.

One insecticide, seven biopesticides and one control were used as treatment. The treatments were $T_{1}=$ cow urine $(1: 1), T_{2}=$ cow urine (1:2), $\mathrm{T}_{3}=$ cow milk (1:1), $\mathrm{T}_{4}=$ cow milk (1:2), $\mathrm{T}_{5}=$ chilli dust $(100 \mathrm{~g} / \mathrm{L}$ water $)$, $\mathrm{T}_{6}=$ neem leaf extract $(1: 2), \mathrm{T}_{7}=$ garlic extract (1:2), $\mathrm{T}_{8}=$ Malathion $(0.2 \%)$ and $\mathrm{T}_{9}=\mathrm{control}$ (untreated). The treatments were sprayed four times at an interval of 10 days from just disease initiation. Weeding was done just before fertilizer application. At the time of weeding proper care was taken so that root did not get injury. Other intercultural operations were done as per needed and to maintain the normal hygienic condition of crop in the field. The plots were inspected regularly to take observations on chilli leaf curl virus disease from seedling to maturity stage of the crop. The last harvest of fresh chilli was performed on May 18, 2015.

Data were recorded on leaf curl infected plants (\%), diseases reduction over control (\%), plant height at harvest $(\mathrm{cm})$, number of fruits/plant, weight of fruits/plant $(\mathrm{g})$, yield $(\mathrm{t} / \mathrm{ha})$ and yield increased over control. Percent data were transformed as square root. The recorded data were analyzed. The means for all the treatments were calculated and the analysis of variance was studied by F-test for the treatment means and replication means. The mean differences were evaluated for their significant level by Duncan's Multiple Range Test (DMRT) as narrated by Gomez and Gomez (1984).

\section{Results and Discussion}

\section{Effect of biopesticides on plants infected with leaf curl virus of Chilli}

Results of biopesticides in reducing leaf curl virus of chilli are presented in Table 1. Infected plants were significantly affected by the biopesticides. Infected plants ranged from 14.75 to $26.85 \%$, where the maximum infected plants were recorded in untreated control which was not statistically similar to all other treatments, but the minimum infected plants was in Malathion ( $0.2 \%)$ sprayed plots which was statistically identical to all other biopesticides except Cow urine (1:2). The highest disease reduction (45.13\%) over untreated control was obtained from Malathion $(0.2 \%)$ followed by Cow urine (1:1) and Neem leaf extract (1:2), and the lowest (26.37\%) was obtained from cow milk (1:2).

Table 1: Effect of biopesticides on infected leaf curl virus of Chilli

\begin{tabular}{|l|c|c|}
\hline Treatments & Leaf curl infected plants (\%) & Disease reduction over control (\%) \\
\hline Cow urine (1:1) & $16.45 \mathrm{bc}(4.05)$ & 38.79 \\
\hline Cow urine $(1: 2)$ & $18.89 \mathrm{~b}(4.34)$ & 29.69 \\
\hline Cow milk $(1: 1)$ & $17.55 \mathrm{bc}(4.19)$ & 34.69 \\
\hline Cow milk (1:2) & $19.78 \mathrm{~b}(4.44)$ & 26.37 \\
\hline Chilli dust (100g/5 L water) & $17.25 \mathrm{bc}(4.15)$ & 35.81 \\
\hline Neem leaf extract (1:2) & $16.90 \mathrm{bc}(4.10)$ & 37.11 \\
\hline Garlic extract (1:2) & $17.77 \mathrm{bc}(4.21)$ & 33.87 \\
\hline Malathion $(0.2 \%)$ & $14.75 \mathrm{c}(3.84)$ & 45.13 \\
\hline Control & $26.85 \mathrm{a}(5.18)$ & - \\
\hline F-test & $*$ & - \\
\hline
\end{tabular}

NS=Not significant 
Means bearing same letter(s) within same column do not differ significantly at $5 \%$ level of significance.

Data in parentheses indicate square root transformation.

\section{Effect of biopesticides on yield and yield contributing characters of Chilli}

Results of biopesticides on yield and yield contributing characters of Chilli are presented in Table 2. Biopesticides showed significant effect on yield and yield contributing characters of Chilli. But plant height was not statistically significant within the treatments. The highest plant height $(55.30 \mathrm{~cm})$ was obtained from cow urine $(1: 2)$ sprayed plots and the lowest $(52.60 \mathrm{~cm})$ was in control plots. The highest number of fruits per plant $(95.67)$ was recorded in Malathion $(0.2 \%)$ which was followed by Neem leaf extract (1:2), Cow milk (1:1) and Cow urine (1:1) sprayed plots and the lowest of the parameter was in untreated control. The highest weight of fruits per plant (119.58 g) was recorded in Malathion $(0.2 \%)$ which was followed by Neem leaf extract (1:2), Cow milk (1:1) and Cow urine (1:1) sprayed plots, and the lowest of the parameter was in untreated control. The fresh yield of chilli ranged from 11.28 to $18.33 \mathrm{t} / \mathrm{ha}$, while the highest fresh yield was obtained from Malathion (0.2\%) which was statistically similar to Cow urine (1:1) and Neem leaf extract (1:2) sprayed plots, and the lowest fresh yield was obtained from untreated control plots. The highest fresh yield $(62.53 \%)$ increased over untreated control was recorded in Malathion $(0.2 \%)$ followed by Cow urine (1:1) and Neem leaf extract (1:2), and the lowest reduction of fresh yield (31.93\%) was recorded in cow milk (1:2) spray.

Table 2: Effect of biopesticides on yield and yield contributing characters of Chilli

\begin{tabular}{|l|c|c|c|c|c|}
\hline Treatments & $\begin{array}{c}\text { Plant height } \\
\text { at harvest (cm) }\end{array}$ & $\begin{array}{c}\text { No. of } \\
\text { fruits/ plant }\end{array}$ & $\begin{array}{c}\text { Weight of } \\
\text { fruits/plant (g) }\end{array}$ & $\begin{array}{c}\text { Fresh } \\
\text { Yield (t/ha) }\end{array}$ & $\begin{array}{c}\text { Yield increased } \\
\text { over control (\%) }\end{array}$ \\
\hline Cow urine (1:1) & 53.63 & $86.95 \mathrm{~b}$ & $110.18 \mathrm{~b}$ & $17.47 \mathrm{a}$ & 54.91 \\
\hline Cow urine (1:2) & 55.30 & $85.70 \mathrm{~b}$ & $107.24 \mathrm{c}$ & $15.76 \mathrm{~b}$ & 39.74 \\
\hline Cow milk (1:1) & 52.95 & $87.25 \mathrm{~b}$ & $109.06 \mathrm{~b}$ & $16.76 \mathrm{~b}$ & 48.61 \\
\hline Cow milk (1:2) & 53.26 & $83.33 \mathrm{~b}$ & $104.16 \mathrm{~d}$ & $14.88 \mathrm{~b}$ & 31.93 \\
\hline Chilli dust (100g/5 L water) & 54.25 & $85.34 \mathrm{~b}$ & $107.08 \mathrm{c}$ & $15.77 \mathrm{~b}$ & 39.83 \\
\hline Neem leaf extract (1:2) & 54.39 & $88.45 \mathrm{~b}$ & $110.56 \mathrm{~b}$ & $16.98 \mathrm{a}$ & 50.56 \\
\hline Garlic extract (1:2) & 54.80 & $85.29 \mathrm{~b}$ & $106.20 \mathrm{c}$ & $16.25 \mathrm{~b}$ & 44.08 \\
\hline Malathion (0.2\%) & 53.49 & $95.67 \mathrm{a}$ & $119.58 \mathrm{a}$ & $18.33 \mathrm{a}$ & 62.53 \\
\hline Control & 52.60 & $69.95 \mathrm{c}$ & $89.44 \mathrm{e}$ & $11.28 \mathrm{c}$ & - \\
\hline F-test & $\mathrm{NS}$ & $*$ & $*$ & $*$ & \\
\hline
\end{tabular}

NS=Not significant

Means bearing same letter(s) within same column do not differ significantly at $5 \%$ level of significance.

\section{Relationship between disease incidence and yield using biopesticides against leaf curl virus of chilli}

Relationship between disease incidence and yield using biopesticides against leaf curl virus of chilli are shown in Fig. 1. The relationship of yield was negatively correlated $\left(r=-0.9816^{* *}\right)$ with disease incidence. The regression lines indicate that with the increase of disease incidence decreases the yield of chilli. The relationships were also expressed in the form of regression equation $y=-0.5759 x+26.576$.

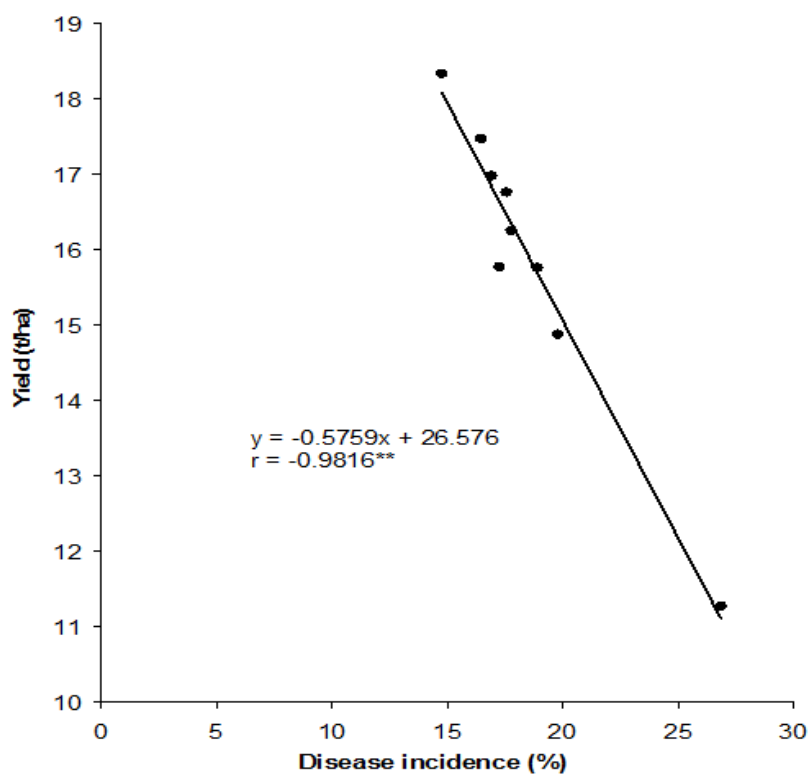

Fig. 1: Relationship between disease incidence and yield using biopesticides against leaf curl virus of chilli 
It was observed from the above study that all the treatments including the test insecticide Malathion (0.2\%) showed significant reduction of leaf curl disease of chilli. The lowest incidence was due to Malathion followed by Cow urine (1:1), Neem leaf extract (1:2) and Chilli dust (100g/5L) treatments. Malathion reduced the disease. Using botanicals, cow milk and cow excreta some success stories have been reported recently by a number of workers. Neem-based commercial products are also available to reduce vector infestation and reduction of viral disease in plants. Recent work of Pandy et al. (2010), Kumar (2007), Kumar (2006), Ismitha and Giraddi (2006), Patel et al. (2006), Fugro (2002), Tripathi et al. (2002), Chakraborti (2000), Khan et al. (2000), Rashid and Khan (2000), Harbant et al. (1999), Singh and Sharma (1999) and Kumar and Vyas (1998) demonstrated the use of botanicals, milk or cow urine in reducing the incidence of insect vectors, reducing viral disease of crops and improvement of yield. In the present study with chilli, in terms of plant growth, height at harvest, no significant difference was obtained as compared with the control. However, the yield increase was significant due to treatments with extract of botanicals, cow urine and cow milk. The yield increase of fresh chilli due to application of cow urine (1:1) was found comparable to the commercial synthetic insecticide Malathion $(0.2 \%)$. Natural products such as cow urine are environmentally safe and eco-friendly and cost effective.

\section{CONCLUSION}

It may be concluded that all the biopesticides and Melathion $(0.2 \%)$ resulted least disease incidence and more yield compared to control. Among the biopesticides, cow urine (1:1), cow milk (1:1) and neem leaf extract (1:2) showed comparatively better results. So, Melathion or biopesticides, cow urine (1:1), cow milk (1:1) and neem leaf extract (1:2) may be sprayed in controlling vector as well as leaf curl virus and increasing fresh yield of chilli.

\section{REFERENCES}

Agri Diary. 2012. Agriculture Information Services, Ministry of Agriculture,

Anonymous. 1960. Index of Plant Disease in the United States. Agricultural Head Book No. 165. U.S. Department of Agriculture. p. 531.

Anonymous. 1966. Index of Plant Virus Disease. Agricultural Head Book No. 307 U.S. Department of Agriculture. p. 446.

Anonymous. 2011. Krishi Projukti Hatboi (Handbook on Agro-technology), $5^{\text {th }}$ edition, Bangladesh Agricultural Research Institute, Gazipur 1701, Bangladesh.

Chakraborti, S. 2000. Neem based integrated schedule for the control of vectors causing apical leaf curling in chilli. Pest Manag. and Econo. Zoology. 8(1): 19-84.

Fernando, H.E., and J.W.L. Peiris. 1875. Investigation on the chilli leaf, curl complex and its control. Trop. Agric. 13: 305-323.

Fugro, P.A. 2000. Role of organic pesticides and manures in management of some important chilli disease. J. Mycol. and Pl. Pathol. 30(1): 96-97.

Gomez, K. A. and A. A. Gomez. 1984. Statistical Procedures for Agricultural Research $2^{\text {nd }}$ ed., Intl. Rice Res. Inst., John Willy and Sons, New York, Chichester, Brisbane, Toronto, Singapore. pp. 187-240.

Harbant, S., V. Korpraditskul, H. Singh, K. Vichai, P. P. Singh and R.C. Saxena. 1999. Evaluation of some plant extracts for the control of Colletotrichum capsici (SYD.) Butter and Bisby, the causal agent of chilli anthracnose. Azadiracta indica A. Juss. Mara Inst of Tech, Malaysia. 12: 131-138.

Ismitha M.S. and R.S. Giraddi. 2006. Efficacy of new acaricides, botanicals and bioagents yellow mite polyphagotarsonemus latus (BANKS) on chilli. Indian J. Entomol. 68(1): 31-35.

Joshi, M.C. and D.P. Singh. 1975. Chemical composition in Bell pepper. Indian Hort. 20: 19-20.

Khalequzzaman KM, Uddin MK, Hossain MM and Hasan MK. 2016. Effect of Fungicides in Controlling Wilt Disease of Cumin Malaysian Journal of Medical and Biological Research, 3, 69-74.

Khalequzzaman, K. (2015). Management of Anthracnose of Hyacinth Bean for Safe Fresh Food Production. Asian Journal of Applied Science and Engineering, 4(2), 102-109.

Khalequzzaman, K. (2015). Screening of BARI Rhizobium Biofertilizers against Foot and Root Rot of Chickpea. ABC Journal of Advanced Research, 4(2), 97 - 104.

Khalequzzaman, K. (2016). Control of Foot and Root Rot of Lentil by using Different Management Tools. ABC Journal of Advanced Research, 5(1), 35 - 42.

Khalequzzaman, K. (2016). Effect of Fungicides in Controlling Alternaria Blight of Cumin. Asian Journal of Applied Science and Engineering, 5(1), 7-14.

Khan, M., S. Khalid and S. Hassan. 2000. Effect of some neem products on transmission of cotton leaf curl virus through Bemisia tabaci. Sarhad J. Agric. 16(6): 593-600.

Khare, M.N. 1996. Methods to test seeds for associated fungi. Indian Phytopath., 49: 319-328.

Kumar, A. 2006. On farm management of leaf curl disease in chilli under arid farming system. J. food Agric. Envir. 4: 180-182. 
Kumar, A. 2007. Managing plant diseases through milk: an innovative approach. BVAAP 15(1): 63-66.

Kumar, A. and N.I. Vyas. 1998. Effects of cow milk on Leaf curl virus of chilli. Honey Bee 9(3): 14.

Pandey Susheel, K., A. C. Mathur and M. Srivastava. 2010. Management of Leaf Curl Disease of Chilli (Capsicum annuum L.). Indian J. Virol. 6(4):246-250.

Patel, B.H., J.J. Patel and H. V. Bhatt. 2006. Bio- efficacy of thiomethoxam 25 WG and difenthiuron 50 WP against thrips, Scirotothrip dorsalis hood infesting chilli (Capsicum frutescens L.). Indian J. Entomol. 68(3): 274-275.

Rashid, A. and M. A. Khan. 2000. Evaluation of antagonistic microbes and bio-insecticides against leaf curl virus and bacterial blight of cotton. Pakistan J. Phytopath. 12(2): 137-141.

Singh, S.S. and R.K. Sharma. 1999. Control trial on chilli mosaic virus after inhibiting there infectivity by leaf juices of some angiospermic plants. J. Living World, 6(2): 18-21.

Sugiura, M., C.M. Bandaranayake and G.H. Hemachandra. 1975. Chilli virus disease in Sri Lanka. Tech; Bull. TARC. Japan. No.8.

Tripathi Savarni, Anupam Varma, S. Tripathi and A. Verma. 2002. Eco-Friendly management of leaf curls disease of tomato. Indian Phytopath. 55(4): 473-478. 
